Sukri Nyompa, Rosmini Maru, Amal Arfan, Alief Saputro, Rabi’ah, 2021, Analisis Karakteristik Sosial Ekonomi Juragan di Pulau Barrang Lompo Kota Makassar

\title{
Analysis of the Socio-Economic Characteristics of the Skipper in Barrang Lompo Island Makassar City
}

\author{
Sukri Nyompa ${ }^{1}$, Rosmini Maru ${ }^{2}$, Amal Arfan $^{3}$, Alief Saputro $^{4}$, Rabi'ah $^{5}$ \\ ${ }^{123}$ JURUSAN GEOGRAFI / FAKULTAS MATEMATIKA DAN ILMU PENGETAHUAN \\ ALAM / UNIVERSITAS NEGERI MAKASSAR \\ ${ }^{4}$ MAHASISWA MAGISTER PENDIDIKAN GEOGRAFI / PROGRAM PASCASARJANA / \\ UNIVERSITAS NEGERI MAKASSAR \\ ${ }^{5}$ MAHASISWA PRODI PENDIDIKAN GEOGRAFI / FAKULTAS MATEMATIKA DAN ILMU \\ PENGETAHUAN ALAM / UNIVERSITAS NEGERI MAKASSAR
}
Email :
sukrinyompa@unm.ac.id ${ }^{1}$,rosminimaru@unm.ac.id ${ }^{2}$, amalarfan@unm.ac.id ${ }^{3}$, aliefsaputro23@gmail.com ${ }^{4}$, kadirrabiah716@gmail.com ${ }^{5}$

(Received: Agu/2021; Reviewed: Sept/2021; Accepted: Sept/2021; Published: Okt/2021)

\begin{abstract}
Barrang Lompo Island is one of the islands located on the west coast of Losari Makassar City with different socio-economic characteristics of the population. The purpose of this study is to analyze the socio-economic characteristics of the skipper and their contribution to the household income of the skipper's family on the island of Barrang Lompo. The analysis of this study used descriptive statistics. The data used are primary and secondary data presented in the form of percentages, cross tables, and pictures. The results of this study can be seen by gender, age, education, income, ethnicity, regional origin, number of crew employed on the ship, number of dependents and the contribution of income. However, the government needs to take strategic policies to improve the welfare of fishermen on Barrang Lompo Island in particular and the population in general.
\end{abstract}

Keywords: socio-economic characteristics; skipper; barrang lompo island

\section{ABSTRAK}

Pulau Barrang Lompo merupakan salah satu pulau yang berada disebelah barat pantai losari kota Makassar dengan dengan karakteristik penduduk sosial ekonomi yang berbeda-beda. Tujuan penelitian ini analisis karakteristik sosial ekonomi Juragan dan kontribusinya terhadap pendapatan rumah tangga keluarga Juragan di pulau Barrang Lompo. Analisis penelitian ini menggunakan statistik deskriptif. Data yang digunakan data primer dan sekunder yang dipersembahkan dalam bentuk presentase, tabel silang, dan gambar. Hasil penelitian ini dapat diketahui jenis kelamin, umur, pendidikan, pendapatan, etnik, asal daerah, jumlah anak buah kapal yang diperkerjakan, jumlah tanggungan dan kontribusi pendapatan Juragan bersama keluarga dapat memenuhi kebutuhan rumah tangga keluarganya dalam sebulan. Namun demikian pemerintah perlu mengambil kebijakan yang strategis 
untuk meningkat kesejahteraan nelayan di pulau Barrang Lompo pada khususnya dan penduduk pada umumnya.

Kata Kunci: karakteristik sosial ekonomi; juragan, pulau barrang lompo.

\section{PENDAHULUAN}

Ditinjau dari segi geografis, kawasan pesisir terletak pada wilayah transisi antara darat dan laut. Menurut (Saputro et al., 2019) bahwa sektor pesisir dan lautan Indonesia memiliki keanekaragaman hayati (mega biodiversity) dengan persentase tertinggi dari negera lainnya. Sebagian besar penduduk yang hidup di wilayah tersebut disebut sebagai masyarakat nelayan. Masyarakat nelayan didefinisikan sebagai kesatuan sosial kolektif masyarakat yang hidup di kawasan pesisir dengan mata pencahariannya menangkap ikan di laut.

Ada beberapa permasalahan yang dihadapi nelayan diantaranya: 1) kemiskinan, kesenjangan sosial serta tekanan ekonomi, 2) Keterbatasan akses modal, teknologi maupun pasar, 3) lemahnya fungsi lembaga sosial ekonomi yang ada di masyarakat, 4) rendahnya kualitas sumberdaya manusia yang berdampak pada keterbatasan akses pendidikan, kesehatan dan pelayanan publik, 5) degradasi sumberdaya lingkungan, baik di kawasan pesisir, laut, maupun pulau-pulau kecil dan 6) belum kuatnya kebijakan yang berorientasi pada kemaritiman sebagai pilar utama pembangunan nasional (Kusnadi, 2003). Hal serupa diungkap oleh (Nyompa et al., 2020) bahwa permasalahan sosial ekonomi merupakan masalah yang masih menghantui masyarakat Indonesia yang tidak pernah habisnya.

Menurut (Utsman, 2007) bahwa nelayan dalam menghadapi kekerasan hempasan ombak dan tiupan angin lautan dan kerja keras serta keuletannya untuk memperjuangkan hidup, nelayan dengan teknologi yang dapat dimanfaatkannya sangat jauh ketinggalan (karena teknologi penangkapan ikan berkembang sangat cepat) dari nelayan modern.

Pendidikan nelayan mempunyai kualitas pendidikan yang sangat rendah yaitu hanya sampai pada tingkat Sekolah Dasar bahkan tidak tamat Sekolah Dasar. Hal ini disebabkan karena kondisi keuangan yang tidak cukup memadai untuk keperluan sekolah. Selain itu kesadaran yang masih kurang tentang pentingnya pendidikan untuk mencapai masa depan yang lebih baik. Menurut (Kusnadi, 2003) bahwa salah satu masalah yang dihadapi oleh masyarakat pesisir adalah kualitas sumbedaya manusia (SDM) yang rendah karena tingkat pendidikan mereka pada umumnya hanya lulusan/tidak tamat sekolah dasar. Tingkat pendidikan yang rendah disebabkan karena keterbatasan ekonomi, kesadaran pendidikan yang kurang, dan sulitnya lulusan sekolah dasar mengakses sekolah-sekolah menengah lanjutan sebagai akibat hambatan letak geografis, hal tersebut memengaruhi etos kerja nelayan, visi dan misi serta wawasan yang luas tentang bagaimana mengelola potensi sumberdaya ekonomi pesisir secara optimal dan berkelanjutan. Hal serupa diungkap oleh (Ikhsan et al., 2020) bahwa Terbukti dengan tingkat pendidikan masyarakat pesisir yang rendah dan menjadi salah satu bagian penting dalam sebuah masyarakat.

Dalam masyarakat nelayan ada beberapa lapisan, misalnya nelayan pemilik kapal disebut punggawa/Juragan, nelayan pekerja pada pemilik kapal yang disebut sawi dan nelayan tangkap biasa yang bekerja secara individu. Perubahan lapisan nelayan tersebut jelas berdampak pada perubahan sosial ekonomi nelayan. Kesulitan-kesulitan ekonomi tidak memberikan kesempatan 
bagi rumah tangga nelayan meningkatkan kualitas pendidikan anak-anak mereka. Banyak anak yang harus bekerja melaut setelah menyelesaikan pendidikan di sekolah dasar. Di samping itu, kemudahan akses untuk bekerja disektor perikanan tangkap, tuntutan ekonomi keluarga, dan kesulitan dalam mencari peluang-peluang kerja lainnya sebagai akibat kegagalan pembangunan pedesaan, telah memperkuat barisan nelayan dengan tingkat kualitas sumberdaya manusia yang rendah.

Menurut (Purwanti, 2005) bahwa pendapatan merupakan hasil yang diterima dan dari pekerjaan.. Mengukur tingkat pendapatan nelayan dapat diukur dengan cara menghitung beberapa hasil tangkap dan hasil produksi lainnya dalam bentuk rupiah dikurangi dengan modal atau ongkos yang digunakan dalam satu kali menangkap ikan atau berlayar yang juga menjadi tolok ukur status sosial para nelayan. Penelitian (Asnaeni, 2014) mengungkapkan bahwa perubahan sosial yang terjadi pada komunitas nelayan Pulau Barrang Lompo dipicu oleh adanya perubahan sistem nilai, dimana tidak ditemui lagi kebersamaan masyarakat di bibir pantai saat nelayan membawa hasil tangkap, karena hasil tangkap secara langsung didistribusikan ke tempat pelelangan ikan di Kota Makassar. Pulau Baranglompo adalah merupakan salah satu pulau ada di kepulauan Sangkarrang sehingga keseharian aktivitasnya sehingga sebagian penduduknya berprofesi sebagai nelayan dan merupakan pekerjaan utama dalam pemenuhan kebutuhan hidup.

Berdasarkan indikasi di atas, penulis tertarik untuk mengkaji kehidupan nelayan terutama karakteristik sosial ekonomi nelayan Juragan dengan melakukan penelitian dengan judul “Analisis karakteristik sosial ekonomi Juragan di Pulau Barang Lompo Kota Makassar”.

\section{METODE}

Penelitian ini dilaksanakan di Pulau Barrang Lompo, Kota Makassar pada bulan FebruariMei 2021. Adapun variabel yang digunakan dalam penelitian ini yaitu:

a. Karakteristik sosial Juragan

1) Tingkat pendidikan

2) Jumlah Tanggungan

3) Tingkat kesehatan

b. Karakteristik ekonomi Juragan

1) Tingkat pendapatan

2) Tingkat pengeluaran

3) Teknologi penangkapan

Langkah awal yang digunakan dalam penelitian ini adalah mengidentifikasi atau merumuskan masalah menjadi sasaran penelitian, setelah masalah diidentifikasi dan dirumuskan maka ditentukanlah kerangka konsepsional yang berhubungan dengan masalah tersebut berdasarkan teori-teori yang relevan. Tahap ini dimaksudkan untuk memperoleh landasan/kerangka pikir guna mengembangkan perspektif peneliti. kemudian dirancang tujuan dan manfaat dari penelitian ini. Berdasarkan rangkaian dari teori-teori yang relevan ini maka dirumuskanlah suatu kesimpulan dalam bentuk kerangka pikir.

Langkah selanjutnya adalah merumuskan variabel yang masuk dalam penelitian ini yang diidentifikasi secara operasional untuk memperoleh dasar pengukurannya, kemudian di lanjutkan pada tahap perumusan definisi operasional variabel, penentuan populasi dan sampel, serta menentukan teknik yang digunakan dalam pengumpulan data dan analisa data. 
Sukri Nyompa, Rosmini Maru, Amal Arfan, Alief Saputro, Rabi'ah, 2021, Analisis Karakteristik Sosial Ekonomi Juragan di Pulau Barrang Lompo Kota Makassar

Setelah tahap diatas selesai, dilanjutkan dengan menyusun daftar pertanyaan (angket) yang akan dibagikan kepada responden. Disamping itu dilakukan pengurusan surat izin penelitian yang akan digunakan sebagai pengantar untuk memperoleh fasilitas serta kemudahan penelitian.

Dalam pelaksanaan penelitian dengan populasi 70 orang yang berprofesi sebagai nelayan juragan dan sekaligus sampel penelitian. Pengumpulan data baik data primer maupun data sekunder dengan menggunakan angket, wawancara, dan dokumentasi. Data disusun dalam bentuk frekuensi da persentase dengan teknik analisis data statistik deskriptif.

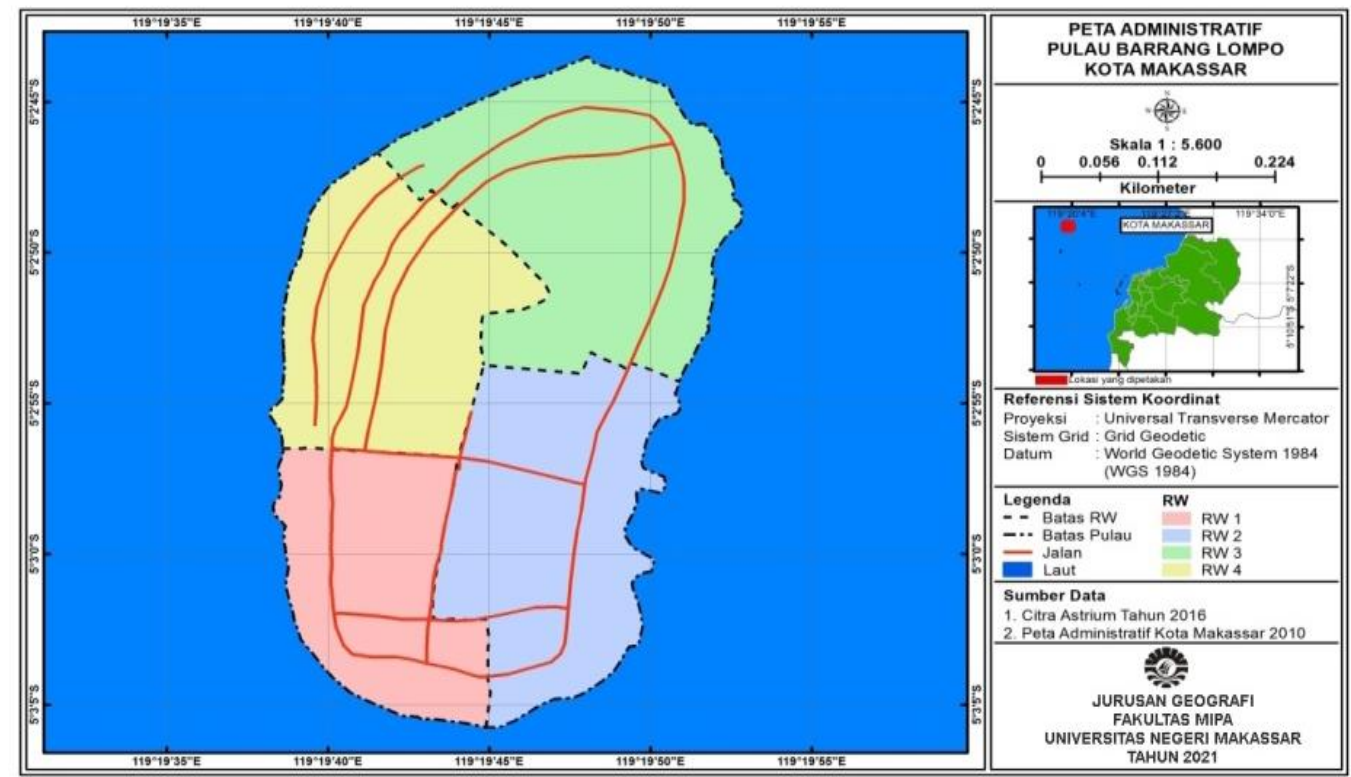

Gambar 1. Peta Lokasi Penelitian

Analisis tabulasi silang adalah metode analisis yang paling sederhana tetapi memiliki daya menerangkan cukup kuat untuk menjelaskan hubungan antar variabel (Singarimbun \& Effendi, 1998). 


\section{Hasil}

\section{HASIL DAN PEMBAHASAN}

\section{Karakteristik Sosial Ekonomi Juragan}

Secara garis besar karakteristik sosial ekonomi Juragan sebanyak 70 kepala keluarga sebagai berikut :

\begin{tabular}{|c|c|c|c|c|}
\hline \multirow{2}{*}{$\begin{array}{l}\text { No } \\
1\end{array}$} & \multicolumn{2}{|c|}{ Karakteristik } & \multirow{3}{*}{$\begin{array}{c}\text { Frekuensi } \\
70 \\
0\end{array}$} & \multirow{3}{*}{$\frac{\text { Persentase \% }}{100}$} \\
\hline & Jenis Kelamin & Laki-laki & & \\
\hline & & Perempuan & & \\
\hline \multirow[t]{2}{*}{2} & Kelompok umur & 20-30 tahun & 50 & 71,4 \\
\hline & & 40-50 tahun & 20 & 28,6 \\
\hline \multirow[t]{3}{*}{3} & Status perkawinan & Belum Kawin & 0 & 0 \\
\hline & & Kawin & 70 & 100 \\
\hline & & Duda & 0 & 0 \\
\hline 4 & Agama & Islam & 70 & 100 \\
\hline \multirow[t]{3}{*}{5} & Tingkat pendidikan & SD & 6 & 8,8 \\
\hline & & SLTP & 18 & 25,7 \\
\hline & & SLTA & 46 & 65,7 \\
\hline \multirow[t]{6}{*}{6} & Jumlah ABK setiap & $<5$ & 1 & 1,5 \\
\hline & juragan & $6-10$ & 16 & 22,8 \\
\hline & & $11-15$ & 30 & 42,8 \\
\hline & & $16-20$ & 9 & 12,9 \\
\hline & & $21-25$ & 7 & 10 \\
\hline & & $>26$ & 7 & 10 \\
\hline \multirow[t]{6}{*}{7} & Lama hari menangkap & $7-14$ & 4 & 6 \\
\hline & ikan di laut & $15-22$ & 6 & 8,5 \\
\hline & & $23-30$ & 20 & 28,5 \\
\hline & & $31-38$ & 17 & 24,2 \\
\hline & & $39-46$ & 17 & 24,2 \\
\hline & & $47-54$ & 5 & 7,1 \\
\hline \multirow[t]{5}{*}{8} & Hasil penangkapan & $<5$ & 37 & 52,86 \\
\hline & ikan/taripang juragan & $6-10$ & 22 & 31,43 \\
\hline & setiap kali turun di laut & $11-15$ & 5 & 7,14 \\
\hline & & $16-20$ & 4 & 5,71 \\
\hline & & $>20$ & 2 & 2,86 \\
\hline \multirow[t]{3}{*}{9} & Pendapatan bersih & $1-5$ juta/bulan & 52 & 74,2 \\
\hline & juragan bersama keluarga & 6-10 juta/bulan & 13 & 18,5 \\
\hline & & $11-15$ juta/bulan & 5 & 7,1 \\
\hline \multirow[t]{3}{*}{10} & Jumlah tanggungan & $<4$ & 28 & 40,00 \\
\hline & & $5-7$ & 35 & 50,00 \\
\hline & & $>8$ & 7 & 10,00 \\
\hline \multirow[t]{2}{*}{11} & Kebutuhan keluarga & Cukup terpebuhi & 64 & 91,43 \\
\hline & & Terpenuhi & 6 & 8,57 \\
\hline
\end{tabular}


email: lageografia@unm.ac.id

Jurusan Geografi Fakultas Matematika dan Ilmu Pengetahuan Alam

Universitas Negeri Makassar Sulawesi Selatan, Indonesia

Sukri Nyompa, Rosmini Maru, Amal Arfan, Alief Saputro, Rabi'ah, 2021, Analisis Karakteristik Sosial Ekonomi Juragan di Pulau Barrang Lompo Kota Makassar

\begin{tabular}{|c|c|c|c|c|}
\hline \multirow[t]{11}{*}{12} & Daerah tangkapan & Kalimantan & 37 & 53 \\
\hline & ikan/taripan & Jawa & 7 & 10 \\
\hline & & NTT & 1 & 1,4 \\
\hline & & Sorong & 3 & 4,2 \\
\hline & & Pangkep & 12 & 17,1 \\
\hline & & Kota Baru & 2 & 2,8 \\
\hline & & Karamean & 2 & 2,8 \\
\hline & & Makassar & 2 & 2,8 \\
\hline & & Maluku & 1 & 1,4 \\
\hline & & Barru & 2 & 2,8 \\
\hline & & Majene & 1 & 1,4 \\
\hline \multirow[t]{10}{*}{13} & Modal awal juragan & $1-10$ juta & 4 & 6 \\
\hline & & $11-20$ juta & 7 & 10 \\
\hline & & $21-30$ juta & 6 & 8,5 \\
\hline & & $31-40$ juta & 6 & 8,5 \\
\hline & & $41-50$ juta & 13 & 18,5 \\
\hline & & $51-60$ juta & 4 & 6 \\
\hline & & $61-70$ juta & 8 & 11,4 \\
\hline & & $71-90$ juta & 4 & 6 \\
\hline & & $91-100$ juta & 15 & 21,4 \\
\hline & & $100-200$ juta & 3 & 4 \\
\hline \multirow[t]{10}{*}{14} & Modal akhir juragan & $1-10$ juta & 5 & 7,2 \\
\hline & & $11-20$ juta & 1 & 1,2 \\
\hline & & $21-30$ juta & 3 & 4,2 \\
\hline & & $31-40$ juta & 5 & 7,1 \\
\hline & & $41-50$ juta & 13 & 18,6 \\
\hline & & $51-60$ juta & 23 & 32,6 \\
\hline & & $61-70$ juta & 4 & 5,8 \\
\hline & & $71-90$ juta & 4 & 5,8 \\
\hline & & $91-100$ juta & 10 & 13,3 \\
\hline & & $100-200$ juta & 3 & 4,2 \\
\hline \multirow[t]{3}{*}{15} & Etnik & Makassar & 60 & 85,71 \\
\hline & & Bugis & 6 & 8,57 \\
\hline & & Mandar & 4 & 5,71 \\
\hline \multirow[t]{5}{*}{16} & Tempat lahir & Barrang Lompo & 47 & 67,14 \\
\hline & & Makassar & 9 & 12,86 \\
\hline & & Pangkep & 5 & 7,14 \\
\hline & & Maros & 4 & 5,71 \\
\hline & & Lain-lain & 5 & 7,14 \\
\hline
\end{tabular}

Sumber: Hasil Analisis data, 2021 


\section{Pembahasan}

Masyarakat di Pulau Barrang Lompo terdiri dari berbagai etnik atau suku dari berbagai asal daerah di wilayah kota Makassar maupun di luar kota Makassar. Disamping itu didominasi beragama islam. Karakteristik sosial ekonomi Juragan meliputi jenis kelamin 100 persen lakilaki, umur Juragan berada pada umur produktif antara 20 - 50 tahun sehingga tidak heran mereka memiliki kemampuan untuk melakukan penangkapan ikan/taripan bersama sawinya sehingga mereka terus berusaha turun laut mencari ikan dalam rangka memenuhi kebutuhan hidupnya, disamping itu semua Juragan sudah berstatus kawin dan beragama islam.

Adapun pendidikan Juragan sebahagian besar berpendidikan SMA/Sederajat, sisanya berpendidikan SMP/Sederajat dan SD. Pendidikan Juragan sangat diperlukan dalam pengembangan sumber daya keluarga yang berkualitas karena merupakan salah satu aspek sosial yang memiliki peranan yang sangat penting. Menurut (Hendrawan et al., 2018) bahwa pendidikan nelayan menjadi salah satu penentu produktifitas dalam melaksanakan pekerjaan.

Para Juragan mampu memiliki anggota (sawi) antara 11 - 15 orang yang bekerja bersama-sama mencari/menangkap ikan terutama taripan bahkan ada Juragan mempunyai sawi sampai 26 orang terutama Juragan yang memiliki kapal besar penangkap ikan/taripan sampai 54 hari lamanya di laut dan paling sedikit waktu yang digunakan hanya 7 hari. Hasil tangkap ikan laut sangat berpengaruh dalam meningkatkan pendapatan masyarakat nelayan, hal tersebut disebabkan oleh factor banyak ikan yang diperoleh sehingga semakin besar pula pedapatan nelayan yang diterima (Lanadimulya \& Dikdik Kusdiana SE, 2018).

Berdasarkan lamanya mencari/menangkap ikan/taripan berpengaruh terhadap jumlah perolehan ikan/taripan yang didapat bahkan ada Juragan mendapat hasil tangkapan ikan terutama taripan dapat mencapai sekitar lebih 20 juta rupiah secara kotor jika di uangkan sekali turun ke laut menangkap ikan terutama taripan apalagi wilayah tangkapan melewati batas provinsi sampai di pulau Jawa dan Sorong yang paling jauh serta pulau Kalimantan yang paling banyak di datangngi Juragan untuk menangkap ikan/taripan, sedangkan di wilayah Sulawesi Selatan, diantaranya wilayah kabupaten Pangkep bahkan sampai di wilayah Sulawesi Barat.

Berdasarkan tingkat Pendapatan Juragan secara bersih setelah dikurang semua biaya yang dikeluarkan selama turun menangkap ikan/taripan di laut diantara biaya makan, solar, gaji sawi dan lain lain sangat bervariasi paling tinggi mencapai antara 6 - 10 juta rupiah dan paling rendah antara $1-5$ juta rupiah setiap Juragan yang didapat setiap kali turun berdasarkan lamanya di laut dan wilayah tangkapannya.

Hasil pendapatan Juragan dikaitkan dengan jumlah tanggungan yang bervariasi ditanggung oleh Juragan, diantaranya ada 27 Juragan menanggung anggota keluarga kurang dari 4 orang dan paling banyak anggota keluarga yang ditanggung oleh 6 Juragan adalah masingmasig 8 orang. Dengan demikan kontribusi Juragan terhadap pendapatan rumah tangga keluarga dapat terpenuhi kebutuhan keluarganya.

\section{SIMPULAN DAN SARAN}




\section{Simpulan}

Berdasarkan hasil analisis dan pembahasan, maka dapat di simpulkan bahwa: Karakteristik sosial ekonomi Juragan di Pulau Barrang Lompo Kecamatan Kepulauan Sangkarrang Kota Makassar menunjukkan bahwa kepala keluarga Juragan semuanya berjenis kelamin laki-laki dengan status kawin, beragama islam dan berada pada kelompok umur produktif, kemudian tingkat pendidikan sebahagian besar berpendidikan SMA/sederajat.

Wilayah tangkapan ikan/taripan para Juragan, selain di wilayah Sulawesi Selatan dan Sulawesi Barat juga diluar termasuk di wilayah pulau Jawa, pulau Kalimantan dan Sorong dengan menggunakan anak buah kapal/sawi antara 11 - 15 orang bahkan ada sampai 26 orang dalam satu kapal penangkapan ikan/taripan.

Namun dari segi besarnya Pendapatan Juragan setiap bulannya bergantung dari jumlah tanggungan setiap kepala keluarga, semakin banyak jumlah tanggungan semakin banyak pula jumlah pengeluaran tiap bulannya, ternyata pendapatan Juragan bersama keluarga dapat memenuhi kebutuhan rumah tangga keluarga dalam sebulan.

\section{Saran}

1. Untuk mendukung kelanjutan dan produktivitas Juragan perlu diberikan pengarahan sebelumnya tentang cara menangkap ikan, penggunaan dan pemeliharaan komponen peralatannya;

2. Masih perlu dilakukan penelitian lagi oleh peneliti lain karena masih banyak kekurangan yang terdapat dalam penelitian ini.

\section{DAFTAR RUJUKAN}

Asnaeni, S. (2014). PERUBAHAN SOSIAL EKONOMI KOMUNITAS NELAYAN DI KELURAHAN PULAU BARRANG LOMPO KECAMATAN UJUNG TANAH KOTA MAKASSAR. JKIP, 1(1), 73-79.

Hendrawan, A., Sucahyawati, H., Cahyandi, K., \& Indriyani, L. (2018). Hubungan pendidikan dan organizational citizenship behavior (OCB) terhadap indikator keselamatan nelayan. Prosiding Seminar Nasional Universitas Pekalongan "Job Outlook Mencari Atribut Ideal Lulusan Perguruan Tinggi, 30-40.

Ikhsan, A. M., Hasriyanti, H., \& Syarif, E. (2020). Pendidikan Formal Anak Dalam Perspektif Nelayan Suku Bajo di Kampung Bajo. LaGeografia, 18(3), 269-288.

Kusnadi. (2003). Akar kemiskinan nelayan. LKiS.

Lanadimulya, H., \& Dikdik Kusdiana SE, M. T. (2018). PENGARUH ALAT TANGKAP IKAN, TENAGA KERJA, LAMA MELAUT, DAN BANTUAN PEMERINTAH TERHADAP HASIL TANGKAP IKAN LAUT DI TPI BINUANGEN KABUPATEN LEBAK. Perpustakaan Fakultas Ekonomi dan Bisnis Unpas Bandung.

Nyompa, S., Dewi, N. A. S., \& Sideng, U. (2020). Dampak Keberadaan Tambang Pasir Terhadap Kondisi Sosial Ekonomi Masyarakat di Desa Cimpu Utara Kecamatan Suli Kabupaten Luwu. LaGeografia, 18(2), 137-149.

Purwanti, S. D. (2005). Profil Tenaga Kerja Di Tempat Pelelangan Ikan Tasikagung Kecamatan Rembang Kabupaten Rembang Tahun 2003. Universitas Negeri Semarang.

Saputro, A., Nyompa, S., \& Arfan, A. (2019). Analisis Pemanfaatan Hutan Mangrove dan 
p-ISSN: 1412-8187 e-ISSN: 2655-1284

email: lageografia@unm.ac.id

Jurusan Geografi Fakultas Matematika dan Ilmu Pengetahuan Alam

Universitas Negeri Makassar Sulawesi Selatan, Indonesia

Sukri Nyompa, Rosmini Maru, Amal Arfan, Alief Saputro, Rabi'ah, 2021, Analisis Karakteristik Sosial Ekonomi Juragan di Pulau Barrang Lompo Kota Makassar

Kontribusinya Terhadap Pendapatan Rumah Tangga Masyarakat di Pulau Tanakeke Kabupaten Takalar. LaGeografia, 18(1), 70-81.

Singarimbun, M., \& Effendi, S. (1998). Metode Penelitian Sosial. Jakarta: LP3ES.

Utsman, S. (2007). Anatomi konflik \& solidaritas masyarakat nelayan: sebuah penelitian sosiologis. Pustaka Pelajar. 